\title{
CASH WAQF INVESTMENT AND POVERTY ALLEVIATION: CASE OF TABUNG MASJIDS IN MALAYSIA
}

\author{
Rashedul Hasan ${ }^{1}$, M. Kabir Hassan² and Mamunur Rashid ${ }^{3}$ \\ ${ }^{1}$ Faculty of Business Communication and Law, INTI International University, Malaysia. \\ Email: rashedul.hasan@newinti.edu.my \\ ${ }^{2}$ Department of Economics and Finance, University of New Orleans. Email: mhassan@uno.edu, \\ Phone: 504-280-6163 \\ ${ }^{3}$ UBD School of Business and Economics. Email: mamun.finance@gmail.com. \\ mamunur.rashid@ubd.edu.bn. Phone: +673 7345837.
}

\begin{abstract}
Recent investigations of the financial management practices of mosques in Indonesia have influenced this study, which investigates the ability of mosques in Malaysia to invest cash waqf for development activities. The impact of cash waqf investment is further extended to study the importance of such cash waqf donations toward poverty alleviation. 100 mosques in Melaka and Terengganu are selected for the purpose of conducting a survey using a self-developed questionnaire. Data collected from the survey are tested for their validity and reliability before conducting Structural Equation Modelling (SEM) analysis using Smart PLS 3.0. This study finds that cash waqf donation plays a positive role in increasing the ability of the selected states to alleviate poverty. The negative relationship between cash waqf investment and donation raises the need for a rigorous analysis. A conceptual model integrating cash waqf investment, donation, and poverty alleviation is provided in this study, which is the first of its kind. The results provided by the study will allow regulators and mosque fund managers to understand the significance of cash waqf donations and the importance of effective cash waqf management. Efficient investment of cash waqf can ensure sustainable and perpetual income that will allow a mosque to play a vital role in improving the living standards of the Muslim Ummah. The findings of the study cannot be generalized for all states in Malaysia due to the limitation of purposive sampling.
\end{abstract}

Keywords: Investment; Maqasid-Al-Shariah; Cash Waqf; Poverty Alleviation; Tabung Masjid; Malaysia.

JEL Classifications: F65; L31.

Received : October 05, 2018

Revised : November 15, 2018

Accepted : November 30, 2018 


\section{INTRODUCTION}

Waqf is an instrument for voluntary charity in Islam that has provided considerable contributions to the development of early Islamic society (Chapra, 2008). Since the fall of the Ottoman Empire, waqf has been considered an outdated institution that is no longer relevant to bring about any significant economic changes. Unproductive waqf resources arguably limit the capability of this hist oric institution to plan any major contribution toward the economy of a Muslim country (Kuran, 2001). In such a situation, cash waqf is considered as a feasible solution and several researchers (Saifuddin et al., 2014; Lahsasna, 2010; Ibrahim, Nor et al., 2013) have investigated the possibility of poverty alleviation through the effective utilization of cash waqf contributions from individual donors.

Cash waqf was first introduced during the Ottoman Empire. The practice of cash waqf was permitted in 2007 in Malaysia, and currently six states are offering cash waqf schemes (Abdullah, 2010). There are noticeable differences in cash waqf management between Bangladesh and Malaysia as the State Religious Council is the primary authority to manage cash and donations in Malaysia.

Cash waqf is viewed as a flexible alternative to the traditional waqf structure which allows anyone to participate in voluntary donations with available cash. However, cash waqf contribution was limited in Malaysia due to the lack of knowledge and awareness (Osman et al., 2014). Through the application of the theory of planned behavior, Osman et al., (2014) also identified that attitude, subjective norms, and perceived behavioral control are instrumental in determining cash waqf participation. Htay, Mohamed, \& Osman (2012) identified trustworthiness and cash waqf management as determinants of the level of cash waqf giving in Malaysia.

Cash waqf collection in Malaysia has the potential to grow (Abdullah, 2009), but unfortunately it has not become very popular (Mahamood, 2006) due to the misconceptions of cash waqf application. Such impediments cause concerns toward the implementation of an integrative waqf model proposed by Sadeq (2002) that requires local participation to accumulate waqf resources that could be used to empower the poor. Similar models that incorporated Islamic microfinance concepts with zakah and waqf for poverty alleviation were introduced by Hasan (2010). Pramanik et al. (2015) have also introduced the importance of a waqfbased Islamic microfinance model for poverty reduction. However, the practical application of these theoretical models requires an increased amount of cash donations from waqif which is reported to be low in past studies.

The majority of the past literature on cash waqf has focused on State Religious Islamic Councils (SRICs) - a limited number of studies have investigated the subject within the context of mosques. It should be noted that mosques rely heavily on cash waqf donations, but management cannot efficiently utilize the fund (Adnan, 2013). The internal control procedures of mosques in Malaysia require special attention regarding the segregation of duties element (Masrek et al., 2014). Lack of empirical evidence from the perspective of cash waqf donations in mosques have influenced this study to investigate the importance of efficient investment of cash waqf in attracting more donations and the ability of cash waqf donations in making significant contributions toward poverty alleviation in Malaysia. Results provided 
by this study will benefit both mosque management and donors to understand the significance of cash waqf in making economic contributions.

\section{LITERATURE REVIEW}

The importance of waqf in socio-economic development has been studied extensively in the previous literature (Ibrahim, Amir, \& Masron, 2013; Monzer Kahf, 2003; Zuki, 2012). While the majority of past studies conceptualized the ability of waqf in alleviating poverty (Ahmad, 2015; Hasan, 2010; Khan, 2013; Pramanik et al., 2015; Sadeq, 2002), recent researchers have focused their interest on financing education expenditures through waqf endowments (Mohsin, 2013; Aziz et al., 2013; Bahroni, 2012; Aziz et al., 2014). Therefore, this study explores the significance of waqf endowments in contributing toward poverty alleviation in Malaysia, following the conceptual studies of Ahmad et al., (2012); Ahmad \& Hassan (2015); Aziz et al., (2013), (2014); Harun, Possumah and Shafiai (2014); Harun, Possumah, Shafiai, et al., (2014), and Mahamood and Rahman (2015).

Mosques require a fund to perform such activities, and individual donations are one of the major funding sources. The fund is needed from the establishment of the mosque itself to cover various expenses for certain routine activities including utility expenses, maintenance expenses, and so on. There are other ways mosques manage a fund, including voluntary charity, i.e. zakat, infaq, sadaqah, and waqf. According to available information, the average collected fund for mosques in Indonesia is around Rp. 12 million per month, which is equivalent to USD 16,000 (Adnan, 2013). Cash savings in the banks for mosques in Perak amounted to RM 3,783,680 from 2009 to 2011 (Razak et al., 2014). With more than 10,000 mosques nationwide, mosques are used merely for matters relating to the well-being of the nearby community in Malaysia.

Public entities, including mosques, which utilize public funds as their financial resource should have sound disclosure mechanisms to prove their accountability to the public. Mosques should become more concerned with the transparency and presentation of financial statements due to their dependence on public donations. In recent years, mosque fund management has attracted researcher attention (Adil, Mohd-Sanusi, Jaafar, Khalid, \& Aziz, 2013; Hamdan, Ramli, Jalil, \& Haris, 2013; Mohamed, Masrek, Daud, Arshad, \& Omar, n.d.; Zain, Samsudin, \& Osman, n.d.; Zakariyah, 2016). The majority of these studies are in the context of Malaysia and focus on accounting, accountability, and fund management issues. Sulaiman, Siraj, \& Ibrahim (2008) found that the embezzlement of funds from mosques is more common due to lack of accountability and lack of commitment to accounting. Lack of an internal control system has already been identified in mosques in different parts of Malaysia (Sulaiman et al., 2008; Adil et al. 2013; Wahab, 2008).

Zain et al. (n.d.) have contributed to the literature by discussing several issues and challenges faced by mosques in the Federal Territory of Malaysia. They have observed that while accounting is loosely practiced in the selected mosques, it is pivotal for these mosques to exhibit accountability in pursuing their missionary activities. The difference between accounting practices among mosques in recording income and expenditure is due to the absence of monitoring devices and lack of supervision by authorized personnel. Such findings may not be generalizable to 
mosques in other parts of Malaysia due to the case study approach taken by Zain et al. (n.d.).

The importance of accounting and accountability practices indicated by Zain et al. (n.d.) was further explored by Ludigdo, Unti, \& Widya (2014). Their transcendental phenomenological study on a single mosque revealed that accountability is a spiritual calling defined as the mandate on the dimension of the relationship between human beings and Allah, as well as trust among human beings.

The importance of an internal financial control system in ensuring sound accounting practices has led to the review of a relevant study conducted by Masrek, Mohamed, Daud, Arshad, \& Omar (2014) on 13 district mosques in the central region of Malaysia. Their study adopted a qualitative research approach with an unstructured interview and found that internal control practices by district mosques on both receipts of income and fund disbursement required significant attention regarding the segregation of duties. Thus, their study reflected the findings provided by Zain et al. (n.d.) on mosques in the Federal territory.

The fund management practices of mosques have recently received muchrequired attention based on the studies of Said et al. (2013) and Zakariyah (2016). Said et al. (2013) adopted a cross-sectional data analysis to examine factors contributing to mosque financial performance. Using a structured questionnaire, the study surveyed 203 mosque treasurers from all over Malaysia and reported that good internal control and active involvement of mosque committees in fundraising activities enhance mosque financial performance. These results provide more significance toward having good internal control indicated by Masrek et al. (2014). However, the low adjusted $\mathrm{R}^{2}$ value calls for further exploration of a framework that could better explain the financial performance of mosques.

As such, we have focused on a similar study conducted by Adil et al. (2013) focusing on the financial management practices of mosques in Malaysia. That study utilized an approached similar to Said et al. (2013) and surveyed 193 chairmen and treasurers of mosques in Malaysia with a response rate of 42.2 percent. The study focused on six variables including financial management practices, budget preparation, fund usage, accountability, internal control, and activity planning using a questionnaire based on a seven-point Likert scale. Lack of correlation and regression analysis in the study limit the ability to understand the interrelationships among variables which was present in the study of Masrek et al. (2014).

Mohamed, Masrek, Mohd, Arshad, \& Omar (n.d.) found that there were no standard guidelines to be followed in managing funds collected by mosques. Regarding disclosure of funds collected and expended, some mosques disclosed every detailed item to the public while some mosques kept all the records only for the knowledge of management. Other elements of internal control, such as physical custody, recording of transactions, and authorization were at the acceptable level at Jameq mosques in the central region of Malaysia. In a similar study, Mohamed, Aziz, Masrek, Noorman, \& Daud (2014) suggested that the internal control system practiced by Jameq mosques on both receipts of income and funds disbursement require significant attention. 
The objectives of Shari'ah can be classified into three categories: Daruriyyah (necessities), haijiyyah (requirements), and tahsiniyyah (beautification). Daruriyyat refers to the commands on which the lives of people depend and the neglect of which leads to total disruption and chaos (Kamali, 2008). This component of Maqasid focuses on the establishment and fulfilment of basic needs for human beings, and failure to comply may cause fasad (corruption and crime) on earth as well as eternal remorse on the Day of Judgement. The daruriyyat are those commands that are undoubtedly necessary. Imam Shatibi considers five essential elements under the Maqasid's classification of daruriyyat, including religion (din), life (nafs), intellect ('aql), progeny (nasl), and wealth (mal). Khan \& Ghifari (1992) assert that freedom should be included in the list as the sixth element. While all five necessities are important for a human being to live a healthy life, this study revolves around a specific necessity, i.e., intellect ('aql) that has a wider implication in creating a better community.

Compliance with the principles of Islam is one way to protect ad-din. An-nafs can be preserved by conducting lawful actions that are permissible under Islam. $A l$-'aql refers to the protection of mind and human intellect from any element that could diminish mental and intellectual ability. The fourth element, an-nasl, is preserved through marriage. Finally, the protection of al-mal is possible through lawful earnings.

Cash waqf requires a return from the investment of the endowed capital in a perpetual manner. The investment and return generated from cash waqf should be used for charitable purposes. While Singapore has become an effective model of waqf management through the creation of a subsidiary company (Harun et al., 2012), such initiatives are not found in Malaysia.

Such a structure for cash waqf investment is not available in Malaysia. Contemporary jurists agree with the rule of the permissibility of cash waqf for loans and investment in banks and bonds (Mandeville \& Mandaville, 1979). Mohammad (2011) indicated the importance of cash waqf investment in generating perpetual profits that could ensure donor contribution, benefit beneficiaries, and alleviate poverty. Htay et al. (2012) identified efficient cash waqf investment as a significant determinant of cash waqf giving in Malaysia. The following hypotheses are generated to test the importance of investment to ensure the perpetuity of the cash waqf:

$\mathrm{H}_{1 \mathrm{a}}$ : Cash waqf investment has a positive impact on collection frequency.

$\mathrm{H}_{1 \mathrm{~b}}$ : Cash waqf investment has a positive impact on total collection

$\mathrm{H}_{1 \mathrm{c}}$ : Cash waqf investment has a positive impact on monthly collection.

$\mathrm{H}_{2}$ : Cash waqf collection frequency has a positive impact on poverty alleviation.

$\mathrm{H}_{3}$ : Total collection has a positive impact on poverty alleviation.

$\mathrm{H}_{4}$ : Monthly cash waqf collection has made a positive impact on poverty alleviation.

\section{METHODOLOGY}

Cash waqf has been theoretically proposed as a tool for economic development through poverty alleviation. This study aims to empirically investigate such a theoretical link. The target population for the study involves mosques in 
Terengganu and Melaka. The absence of a sampling frame has led to the random selection of mosques in the selected states. Bartlett, Kotrlik, \& Higgins (2010) have advised a minimum sample size of 118 for a study using continuous data. The ratio of observations to independent variables should not fall below ten (Hair et al., 2009). The current study has four independent variables, and thus a sample size of 120 is selected for the study. At the end of the survey, a total number of 100 usable responses were gathered and used in the data analysis.

The questionnaire for the survey was developed through the review of the literature and thus reliability and validity measures were applied to justify the validity of the instrument. Cronbach alpha values exceeded the recommended value of 0.70 (Cronbach, 1951). The Partial Least Square (PLS) approach using Smart PLS 3.0 was utilized to test the hypotheses generated in the study. A bootstrapping method (500 resamples) was used to determine the significance levels for loadings, weights, and path coefficients (Lowry \& James Gaskin, 2014).

\section{IV.RESULTS AND FINDINGS}

This study uses five variables to investigate the impact of cash waqf investment in attracting donations and its ability toward poverty alleviation. Table 1 provides the descriptive statistics of dependent and independent variables. The mean score for cash waqf collection frequency is 2.62, which indicates that cash waqf is collected on a weekly basis. A mean score of 2.162 for total cash waqf collection in 2015 refers to a range of RM 10,000 to 50,000 collected in cash by the selected mosques. Monthly cash waqf collection ranges from RM 1000 to 5000. The descriptive statistics also indicate that the majority of the cash waqf is invested in the development of the mosque. Finally, the two states were ranked based on the state-wise GINI coefficient in 2015 available on the website of the "Economic Planning Unit" under the Malaysian Prime Minister's Department.

Table 1.

Descriptive Statistics of Variables

\begin{tabular}{lccc}
\hline Variables & Mean & Median & SD \\
\hline CW Collection Frequency & 2.62 & 2 & 1.509 \\
Total CW Collection & 2.162 & 2 & 1.398 \\
Monthly Cash Waqf Collection & 2.04 & 2 & 1.148 \\
Poverty Alleviation & 1.4 & 1 & 0.49 \\
Cash Waqf Investment & 3.61 & 4 & 1.165 \\
\hline
\end{tabular}

Pearson correlation was conducted to check the correlation scores among the studied variables. None of the variables is found to have high correlations with each other, which ensures that the data is not suffering from multicollinearity issues. Independent variables have strong correlations with the dependent variable (poverty alleviation). 
Table 2.

Pearson Correlation Statistics

\begin{tabular}{llccccc}
\hline & $\mathbf{1}$ & $\mathbf{2}$ & $\mathbf{3}$ & $\mathbf{4}$ & $\mathbf{5}$ \\
\hline 1 & CW Collection Frequency & 1 & & & & \\
2 & Total CW Collection & 0.185 & 1 & & & \\
3 & Monthly Cash Waqf Collection & 0.045 & 0.014 & 1 & & \\
4 & Poverty Alleviation & 0.449 & 0.469 & -0.115 & 1 & \\
5 & CW Investment & -0.198 & -0.272 & 0.134 & -0.533 & 1 \\
\hline
\end{tabular}

A two-step approach is used to ensure the validity and reliability of the data gathered through the survey. Following the suggestions of Anderson \& Gerbing (1988), the convergent validity and reliability are assessed first before going through the discriminant validity analysis. Convergent validity can be ascertained if the loadings are greater than 0.50 (Bagozzi \& Yi, 1991), composite reliability greater than 0.70 (Gefen et al., 2000), and the average variance extracted is greater than 0.50 (Fornell \& Lacker, 1981). Data relating to all five variables have satisfied such criteria.

The traditional approach provided by Fornell \& Larcker (1987) does not reliably detect the lack of discriminant validity in common research situations (Henseler et al., 2015). Thus, the heterotrait-monorail ratio of correlations (HTMT) suggested by Henseler et al. (2015) is used in the current study. The recommended value for the HTMT is below 0.90. Table 3 provides the HTMT correlation scores for the study. None of the correlation scores is above the 0.90 threshold and thus the discriminant validity of the data is established.

Table 3.

The Heterotrait-Monotrait Ratio of Correlations (HTMT)

\begin{tabular}{llcccc}
\hline & & $\mathbf{1}$ & $\mathbf{2}$ & $\mathbf{3}$ & $\mathbf{4}$ \\
\hline 1 & CW Collection Frequency & - & & & \\
2 & Total CW Collection & 0.26 & & & \\
3 & Monthly Cash Waqf Collection & 0.05 & 0.73 & & \\
4 & Poverty Alleviation & 0.45 & 0.61 & 0.47 & 0.53 \\
5 & CW Investment & 0.2 & 0.31 & 0.27 & 0.31 \\
\hline
\end{tabular}

Several model fit statistics were extracted from the Smart PLS 3.0 software. First, the Standardized Root Means Square Residual (SRMR) is a measure of the mean absolute value of the covariance residuals. An SRMR value that ranges from 0.08 to 0.10 suggests a good fit (Hu \& Bentler, 1995). However, the current study has an SRMR value of 0.21 . As a result, several other model fit measures that are based on bootstrap inference statistics are explored.

The first among such statistics are the squared Euclidean distance (D_LS) and the geodesic distance (D_G). These statistics were introduced by Henseler et al. (2015) as two separate ways to measure discrepancy. A non-significant value 
ensures the difference between the correlation matrices implied by the empirical model and the empirical correlation matrix and establishes the model fitness. Finally, normed fit index (NFI) is the first measure of model fitness introduced by (Bentler \& Bonett, 1980) that used the Chi-square value of the null model as a benchmark. An NFI value closer to 1 indicates model fitness. The NFI value of the current model is 0.45 and thus validates the model.

Table 4.

Model Fit Statistics

\begin{tabular}{lcc}
\hline Criteria & Values & Recommended Values \\
\hline SRMR & 0.21 & $0.08-0.10$ \\
D_LS & 0.65 & $\mathrm{p}>0.05$ \\
D_G & 0.26 & $\mathrm{p}>0.05$ \\
Chi-Square & 101.8 & Lower is better \\
NFI & 0.45 & Closer to 1 \\
\hline
\end{tabular}

This study proposes a conceptual model to study the impact of cash waqf investment in attracting donations and poverty alleviation. The results of the study support the theoretical proposition in the literature that cash waqf donations can help in poverty alleviation (Saifuddin et al., 2014). The adjusted $\mathrm{R}^{2}$ value of 0.46 indicates that the three variables proxying for cash waqf donations explain 46 percent of poverty alleviation in Melaka and Terengganu.

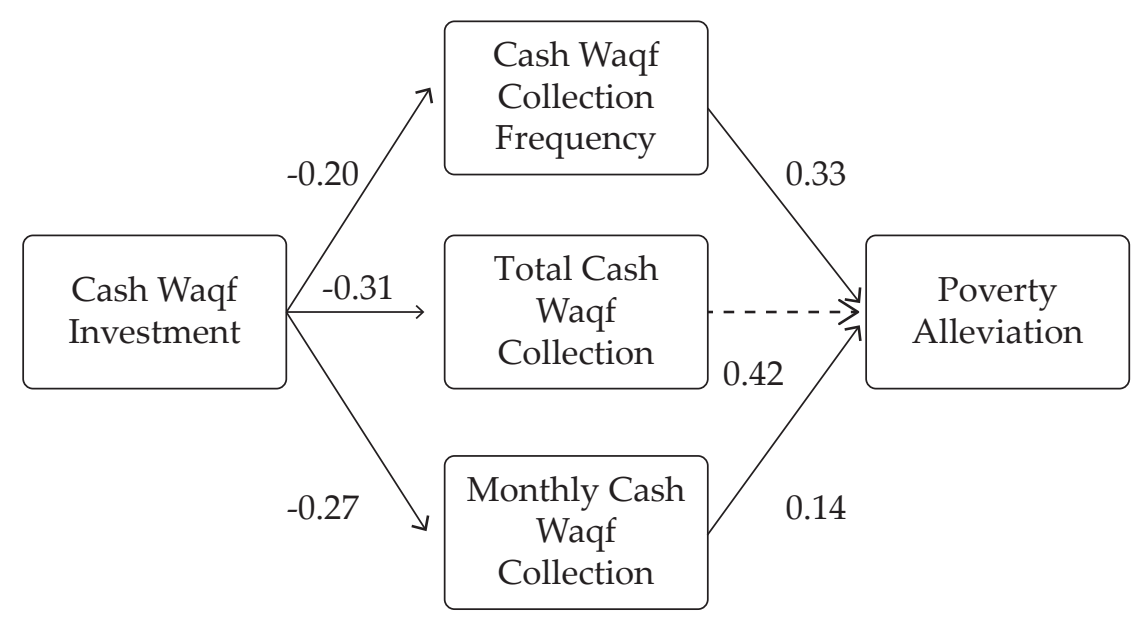

Note: Dotted line represents insignificant relationships

Figure 1. Results of the Structural Model Analysis 
The study hypothesises six relationships. Cash waqf investment is hypothesised to have a positive effect on the frequency of cash waqf collections. Such a relationship is not established due to a non-significant relationship. Thus, $\mathrm{H}_{1 \mathrm{a}}$ is rejected. Similarly, $\mathrm{H}_{1 \mathrm{~b}}$ and $\mathrm{H}_{1 \mathrm{c}}$ are also rejected due to the non-significant values. However, the negative direction of the coefficient value indicates that cash waqf investment has a negative impact on the amount of cash waqf donations. It was discussed earlier that the majority of mosques invest cash waqf on development, which does not allow any perpetual return. Thus, donors may not feel confident in increasing the level of cash donations to the mosque as they have limited ability to generate a perpetual return that could assist beneficiaries.

$\mathrm{H}_{2}$ is formulated to propose a positive relationship between cash waqf collection frequency and poverty alleviation. A positive coefficient value $(\beta=0.33, p<0.01)$ indicates that more frequent cash waqf collection can make a positive impact on a state's ability to reduce poverty. Thus, $\mathrm{H}_{2}$ is accepted. Cash waqf collection in 2015 was hypothesised to have a positive impact on the poverty alleviation ability of the selected states. Such a relationship was not proved, and $\mathrm{H}_{3}$ is rejected. Finally, monthly cash waqf collection was found to have a positive impact on the state's ability to alleviate poverty. Thus, $\mathrm{H}_{4}$ is accepted.

Table 5.

Regression Statistics

\begin{tabular}{lccccc}
\hline Hypothesis & Paths & $\beta$ & T-Statistic & P-Value & Supported \\
\hline $\mathrm{H}_{1 \mathrm{a}}$ & $\begin{array}{c}\text { CW Investment } \rightarrow \text { CW } \\
\text { Collection Frequency }\end{array}$ & -0.2 & 2.04 & 0.04 & No \\
$\mathrm{H}_{1 \mathrm{~b}}$ & $\begin{array}{c}\text { CW Investment } \rightarrow \text { Total CW } \\
\text { Collection }\end{array}$ & -0.31 & 3.07 & 0 & No \\
$\mathrm{H}_{1 \mathrm{c}}$ & $\begin{array}{c}\text { CW Investment } \rightarrow \text { Monthly CW } \\
\text { Collection }\end{array}$ & -0.27 & 3.15 & 0 & No \\
$\mathrm{H}_{2}$ & $\begin{array}{c}\text { CW Collection Frequency } \\
\text { Poverty Allevation }\end{array}$ \\
$\mathrm{H}_{3}$ & $\begin{array}{c}\text { Total CW Collection } \rightarrow \text { Poverty } \\
\text { Allevation }\end{array}$ & 0.33 & 3.93 & 0 & Yes \\
$\mathrm{H}_{4}$ & $\begin{array}{c}\text { Monthly CW Collection } \rightarrow \\
\text { Poverty Allevation } \\
\text { Adjusted R }\end{array}$ & 0.14 & 1.51 & 0.13 & Yes \\
\hline
\end{tabular}

\section{CONCLUSION}

Cash waqf has the potential to make a significant contribution to the economic development of Malaysia. This study focuses on investigating the nature of cash waqf investment undertaken by the management of mosques in two specific states. Through a survey of one hundred mosques in Melaka and Terengganu, this study finds that cash waqf is mostly used for the development of mosques. Investment decisions made by management are further linked with the number of cash waqf donations received by the selected mosques. Although not significant, the negative association between cash waqf investment and several proxies of cash waqf donations provides important areas of concern for the mosque management. 
Cash waqf increases the ability of the selected states to alleviate poverty. Thus, this study contributes to the cash waqf literature by proving the theoretical propositions made in earlier studies. The findings of this study are limited to only two states in Malaysia. Future studies including all states can provide generalizability.

\section{REFERENCES}

Abdullah, M.S. (2010). Malaysia Needs Transformation of Waqf Management.

Abdullah, M.S. (2009). Malaysia perlu Transformasi Pengurusan Wakaf.

Adil, M.A.M. et al. (2013). Financial Management Practices of Mosques in Malaysia. GJAT, 3(1), 23-29.

Adnan, M.A. (2013). An Investigation of the Financial Management Practices of the Mosques in the Special Region of Yogyakarta Province, Indonesia. In Sharia Economics Conference, 1-13.

Ahmad, A., Muhammad, S. bin., \& Kamaruzaman, M.A.S. bin. (2012). Educationa Development through Waqf. In $3^{\text {rd }}$ International Conference on Islam and Higher Education ( ${ }^{\text {rd }}$ ICIHE), 1-22.

Ahmad, M. (2015). Role of Waqf in Sustainable Economic Development and Poverty Alleviation: Bangladesh Perspective. Journal of Law, Policy and Globalization, 42, 118-130.

Ahmad, M., \& Hassan, Y.B. (2015). Funding the Sub-Saharan African Education Sector with Waqf: Experiences from al-Azhar University and Selected Universities in Malaysia. Journal of Creative Writing, 1(2), 40-54.

Anderson, J.C., \& Gerbing, D.W. (1988). Structural Equation Modeling in Practice: A Review and Recommended Two-Step Approach. Psychological Bulletin, 103(3), pp.411-423.

Asdar Ludigdo, Unti, P., \& Widya, Y. (2014). Phenomenological Study of Financial Accountability of Mosque. IOSR Journal of Economics and Finance, 5(4), 10-17.

Aziz, M.R.A. et al. (2014). The Relief of Higher Education Loan Through Islamic Waqf Bank. Asian Social Science, 10(22), 175-181.

Aziz, M.R.A., Johari, F., \& Yusof, M.A. (2013). Cash Waqf Models for Financing Education. In $5^{\text {th }}$ Islamic Economics System Conference (iECONS, 2013). Kuala lumpur, 835-842.

Bagozzi, R.P., \& Yi, Y. (1991). Multitrait-multimethod Matrices in Consumer Research. Journal of Consumer Research, 17(4), pp.426-39.

Bahroni, I. (2012). Streamlining Education Institution Through Waqf Enlargement: An Experience of Gontor System. In International Seminar on Waqf Enlargement. Kuala lumpur, pp. 339-361.

Bartlett, J.E., Kotrlik, J.W., \& Higgins, C.C. (2010). Organizational Research: Determining Appropriate Sample Size in Survey Research. Information Technology, Learning, and Performance Journal, 19(1), 43-50.

Bentler, P.M., \& Bonett, D.G. (1980). Significance Tests and Goodness-of-Fit in the Analysis of Covariance Structures. Psychological Bulletin, 88, 588-600.

Chapra, M.U. (2008). Ibn Khaldun's Theory of Development: Does It Help Explain the Low Performance of the Present-Day Muslim World?. The Journal of SocioEconomics, 37(2), 836-863. 
Chin, W. (1998). The Partial Least Squares Approach for Structural Equation Modeling. Mahwah, NJ: Lawrence Erlbaum Associates.

Cizakca, M. (1998). Awqaf in History and Its Implications for Modern Islamic Economies. Islamic Economic Studies, 6(1), pp.43-70.

Cizakca, M. (1997). Towards a Comparative Economic History of the Waqf System. Al-Shajarah.

Cronbach, L. (1951). Coefficient Alpha and the Internal Structure of Tests. Psychometrika, 16, 297-334.

Fornell, C., \& Lacker, D.F. (1981). Evaluation Structural Equation Models with Unobserved Variables and Measurement Error. Journal of Marketing Research, 18(1), 39-50.

Fornell, C., \& Larcker, D. (1987). A Second Generation of Multivariate Analysis: Classification of Methods and Implications for Marketing Research. Review of marketing, 51, 407-450.

Gefen, D., Straub, D.W.D., \& Boudreau, M.C.M.-C.M.C. (2000). Structural Equation Modeling and Regression: Guidelines for Research Practice. Communications of the Association for Information Systems, 4(7), 1-79. Available at: http://aisel. aisnet.org/ cais/vol4/iss1/7/

Hair, J.J.F. et al. (2009). Multivariate Data Analysis. Pearson. Available at: http:// library.wur.nl/WebQuery/clc/1809603 [Accessed September 2, 2015].

Hamdan, N. et al. (2013). Accounting for Waqf Institutions : A Review on the Adaptation of Fund Accounting in Developing the Shariah Compliant Financial Reports for Mosque. In UITM \& IKAZ, eds. Transforming islamic Philanthropy For Ummah Excellence. UITM.

Harun, F.M. et al. (2014). Empowering Higher Education Institution: The Role of Waqf - Malaysian Perspective. In Australian Academy of Business and Social Sciences Conference.

Harun, F.M., Possumah, B.T., \& Shafiai, M.H. (2014). Cost Benefit Analysis On Government's Education Expenditure: Proposed Waqf Model For Education Capital.

Harun, R., Isa, Z.M., \& Ali, N. (2012). Preliminary Findings on Waqf Management Practices among Selected Muslim Countries. In International Conference on Economics Marketing and Management, 117-120.

Hasan, K. (2010). An Integrated Poverty Alleviation Model Combining Zakat, Awqaf and Microfinance. In $7^{\text {th }}$ International Conference - The Tawhidi Epistemology: Zakat and Waqf Economy.

Henseler, J., Ringle, C.M., \& Sarstedt, M. (2015). A New Criterion for Assessing Discriminant Validity in Variance-based Structural Equation Modeling. Journal of the Academy of Marketing Science, 43(1), 115-135.

Htay, S., Mohamed, M., \& Osman, A. (2012). Determinants of Cash Waqf Giving in Malaysia: Survey of Selected Works. Available at: http://irep.iium.edu. my/28284/ [Accessed May 27, 2015].

Hu, L.T., \& Bentler, P.M. (1995). Evaluating Model Fit. In Structural Equation Modeling: Concepts, Issues, and Applications. Thousand Oaks, CA: Sage, 159-76. 
Ibrahim, H., Amir, A., \& Masron, T.A. (2013). Cash Waqf: An Innovative Instrument for Economic Development. International Review of Social Sciences and Humanities, 6(1), 1-7.

Ibrahim, H., Nor, E., \& Muhammad, J. (2013). Cash Waqf and Its Development in the Northern Region of Malaysia. In $4^{\text {th }}$ International Conference on Business and Economic Research (4 $4^{\text {th }}$ Icber 2013) Proceeding, 276-284.

Kahf, M. (1999). Financing the Development of "Awqaf" Property. The American Journal of Islamic Social Sciences, 16(4), 39-66.

Kahf, M. (2003). The Role of Waqf in Improving the Ummah Welfare. In the International Seminar on "Waqf as a Private Legal Body", 1-26.

Kahf, M. (1992). Waqf and Its Sociopolitical Aspects. IRTI, Jeddah, Saudi Arabia.

Kamali, M.H. (2008). Maqasid Al-Shari'ah Made Simple. International Institute of Islam Thought.

Khan, D.M.T. (2013). Contribution of Islamic Waqf in Poverty Reduction.

Khan, F.M., \& Ghifari, N.M. (1992). Shatibi's Objectives of Shari'ah and some Implications for Consumer Theory. Readings in Islamic Economic Thought, 176.

Kuran, T. (2001). The Provision of Public Goods Under Islamic Law: Origins, Impact, and Limitations of the Waqf System. Law \& Society Review, 35(4), 841897.

Lahsasna, A. (2010). The Role of Cash Waqf in Financing Micro and Medium Size Enterprises (MMES). In Seventh International Conference-The Tawhidi Epistemology: Zakat and Waqf Economy, 97-118.

Lowry, P.B., \& James Gaskin. (2014). Partial Least Squares (PLS) Structural Equation Modeling (SEM) for Building and Testing Behavioral Causal Theory: When to Choose It and How to Use It. IEEE Transactions on Professional Communication, 57(2), 123-146.

Mahamood, S.M. (2006). Waqf in Malaysia: Legal and Administrative Prespectives. Kuala Lumpur: University Malaysia Press.

Mahamood, S.M., \& Rahman, A.A. (2015). Financing Universities Through Waqf, Pious Endowment: Is It Possible?. Humanomics, 31(4), 430-453.

Mandeville, J.E., \& Mandaville, J.E. (1979). Usurious Piety: The Cash Waqf Controversy in the Ottoman Empire. International Journal of Middle East Studies, 10, 33-42.

Masrek, M.N. et al. (2014). Internal Financial Controls Practices of District Mosques in Central Region of Malaysia. International Journal of Trade, Economics and Finance, 5(3), 255-258.

Mohamed, I.S. et al. (2014). Mosque fund management: issues on accountability and internal controls. In Procedia - Social and Behavioral Sciences, 189-194.

Mohamed, I.S., Masrek, M.N., Daud, N.M., Arshad, R., \& Orman, N. (2015). Mosques Fund Management: A Study on Governance and Internal Controls Practices. Recent Advances on Finance Science and Management.

Mohamed, I.S., Masrek, M.N., Mohd, N.D., Arshad, R., \& Orman, N. (2015). Mosques Fund Management: A Study on Governance and Internal Controls Practices. Recent Advances on Finance Science and Management.

Mohammad, M.T.S.H. (2011). Towards an Islamic Social (Waqf) Bank. International Journal of Trade, Economics and Finance, 2(5), 381-386. 
Mohsin, M.I.A. (2013). Financing Through Cash-Waqf: A Revitalization to Finance Different Needs. International Journal of Islamic and Middle Eastern Finance and Management.

Osman, A.F., Mohammed, M.O., \& Amin, H. (2014). An Analysis of Cash Waqf Participation Among Young Intellectuals.

Pramanik, A.H. et al. (2015). Integration of Waqf and Islamic Microfinance for Poverty Reduction: Case Studies of Malaysia, Indonesia and Bangladesh, Kuala Lumpur.

Razak, A.A. et al. (2014). Economic Significance of Mosque Institution in Perak State, Malaysia. Kyoto Bulletin of Islamic Area Studies, 7, 98-109.

Sadeq, A.M. (2002). Waqf, Perpetual Charity and Poverty Alleviation. International Journal of Social Economics, 29, 135-151.

Said, J. et al. (2013). Financial Management Practices in Religious Organizations: An Empirical Evidence of Mosque in Malaysia. International Business Research, 6(7), 111-119.

Saifuddin, F.B. et al. (2014). The Role of Cash Waqf in Poverty Alleviation: Case of Malaysia.

Sulaiman, M., Siraj, S.A., \& Ibrahim, S.H.M. (2008). Internal Control Systems in West Malaysia's State Mosques. The American Journal of Islamic Social Sciences, 25(1).

Wahab, A.A. (2008). Financial Management of Mosques in Kota Setar District: Issues and Challenges.

Zain, S.R.M., Samsudin, M.M. Bin., \& Osman, A.Z. (2015). Issues and Challenges: An Exploratory Case Study on Mosques Institution in Federal Territory.

Zakariyah, L. (2016). Application of Maqāșid al-Sharī‘ah in Managing Mosque Funds: A Case Study of Tabung Masjid in Terengganu, Malaysia.

Zuki, M. (2012). Waqf and Its Role in Socio-Economic Development. ISRA International Journal of Islamic Finance. Available at: http://www.ilovetheuae. com/uploads/waqf.pdf [Accessed May 27, 2015]. 
This page is intentionally left blank 